Published in (1996) 6 Australian Journal of Corporate Law 348

\title{
Berle and Means, Corporate Governance and the Chinese Family Firm
}

\begin{abstract}
Philip Lawton*
While concentrating primarily on the Hong Kong experience this paper will analyse the nature of the Hong Kong Chinese corporation from the point of view of corporate governance. Only in very exceptional circumstances do Chinese business organisations in corporate form develop into anything like the traditional model of the Anglo-American Berle-Means corporation characterised by a separation of ownership and management. Rather, they have strong, culturally based, characteristics which determine a particular type of hierarchical structure and often a tendency, as elsewhere, for a relatively short life cycle of two to three generations. For those, often family dominated, companies which do become listed, problems of compliance with standards of corporate governance imposed by the corporate law and listing rules regimes are common. One of the problem areas which will be explored in this paper is the recent attempt to introduce independent non executive directors, as an example of the imposition of a corporate governance norm which may not be easily accepted in the context of the Chinese family dominated listed company. The corporate and securities regime of Hong Kong is about to undergo a major review. This paper will argue that any review which fails to consider and take account of the cultural context in which legal business vehicles, including registered companies, operate, is liable to exacerbate rather than remedy the compliance and governance problems currently encountered. Before doing so $I$ wish to make some points concerning recent research on the BerleMeans corporation and the influence of history, politics and culture on the various types of governance structure prevalent on today's worldwide corporate scene.
\end{abstract}

\section{Economics, Politics and Culture as Influences on Corporate Structures}

The idea that the Anglo American Berle/Means type of public listed company, characterised by a separation of ownership and management resulting from the need of growing enterprises for capital and the specialisation of management, is the most economically rational of large business organisational forms has been increasingly questioned in recent work. Roe argues that an important part of the Berle-Means corporation is the product of American politics, not just economic necessity. ${ }^{1} \mathrm{He}$ argues that the political element has two parts. The first being that powerful laws barred or restricted intermediaries in governance roles during most of the 20th century, a century which has been essentially one of 
growth for large firms. The second element according to Roe is that there is enough similarity in the pattern behind some of these laws to challenge whether economic evolution alone explains the shape of the large public firm. His thesis is that if the political system fragments intermediaries (and American populism, federalism, and interest groups in fighting did fragment them) then the BerleMeans corporation is inevitable. ${ }^{2}$

The classical economic explanation would, if it were universal in application, tend to predict that nations with similar economics would have similar corporate structures. Just as there may be a best way to manufacture a particular product such as steel, on this approach there is a best way to organise large steel firms. Therefore, managerial incentive compensation schemes, proxy fights, conglomerates takeovers, and boards of independent outsiders, all of which reflect the attempt to reduce the agency costs of organising the large American public firm should play a role in corporate governance in Germany and Japan. According to Roe, the absence of these features in the structures prevalent in Germany and Japan poses a challenge in that it shows that there is more than one way to deal with the large firm's organisational problems. ${ }^{3}$ These differences in corporate structure indicate that differences in political histories, cultures and paths of economic development have a part to play in explaining the different structures. ${ }^{4}$ The purely economic model, although important, must be considered in the context of these other factors and their no doubt complex interrelationships better understood. Therefore, much more research is required to understand and explain the relative role and interaction of each of these and possibly other factors in the development of corporate structures and modes of governance.

In the modern global economy competition exists not only among products, but also among governance systems. It is argued by some that the Chinese family business has a rationality of its own. ${ }^{5}$ According to the Columbian school of thought real world competition has obliged business scholarship to focus on comparative corporate governance and in the light of the sometimes, if not often, better performance of other systems understanding the differences has become urgent. ${ }^{6}$ However, models of governance elsewhere do not simply have the purpose, like the American system of solving the Berle-Means monitoring problem but often serve additional functions. Gilson and Roe have, for example, developed a model of the Japanese Keiretsu as involving not only governance, but also the need to support production and exchange, a system for which they coin the term "contractual governance". I will return to this approach in the context of the Chinese family corporation later, when exploring the concept of networks of personalistic relationships which are often both internal and external to the Chinese firm.

Nevertheless, the Columbian analysis and the role of comparative governance studies has its detractors. In particular, Romano emphasises that without a means to make comparative judgments, truly helpful lessons cannot be drawn from other nations' experiences for the purpose of reforming corporate governance or at least the possibility of doing so is diminished. This undermines the rationale for making comparisons in the first place. Why, for example, should the corporate organisational form produced by a political process that empowers banks be viewed as preferable to a process that does not, 
without evidence of the superiority of the former organisational form? In reviewing extensive data on relative competitiveness she argues that the assumption of the superior competitiveness of German and Japanese firms over US firms is mistaken. ${ }^{8}$ Other recent work by Edwards and Fischer on the merits of the bank based system in Germany, shows that the positive view of that system is not supported by the evidence.The supposed advantages of the bank's control of voting rights and representation on supervisory boards which, inter alia, allow for reduced asymmetric information problems thereby enabling banks to supply more external finance to firms at a lower cost and increase investment; and the control of management of firms on behalf of shareholders ensuring efficiency in terms of agency costs and outputs are overrated, according to Edwards and Fischer. ${ }^{9}$

They do however emphasise that there are many other respects in which Germany differs from eg, the UK or indeed other economies, which may be relevant for relative economic performance since 1945. These other factors could include: Germany's system of education and training, its structure of industrial democracy reducing confrontation between labour and management or contributing to overall efficiency as well as the country's macro economic policy. It is recognised therefore that it is impossible to conclude anything about the contribution of the German financial system to German economic performance on the basis of simple correlations which do not take account of other possible influences. ${ }^{10}$ Nevertheless, problems of comparative study aside, the point is well made that other factors are relevant in the understanding of economic competitiveness, the development of corporate structures and their legal regimes.

In this regard three basic points may be made about Hong Kong's economy and the nature of its largely family dominated businesses. They are first that its economy has some crucial differences particularly in its use of capital. Redding has argued that when comparing the overseas Chinese economies at large including Hong Kong's, with those of Japan, Europe and North America, the way capital is used in those Chinese contexts is different. There is a different strategic tendency, indicated by (a) the proliferation of small firms among the overseas Chinese, (b) the avoidance of highly complex, integrated, capital intensive structures such as are needed in car manufacture and heavy industry and (c) the tendency to concentrate in property, banking, commercial trading, and small scale manufacture. ${ }^{11}$ This facet is closely interrelated with the second point namely the nature of the Chinese family firm, its strengths and problems in relation to its patrimonialistic control, the close relationship between authority and ownership and the firms external relationships being largely dependant on personalistic networks with suppliers, customers and other third parties. ${ }^{12}$ This in turn leads to the third proposition which is also closely related to the first two, namely the relatively short life cycle of Chinese businesses and the fact that few Chinese companies in Hong Kong have reached the stage of separation of ownership and management. When they do there is a strong tendency to split up rather than successfully negotiate such a separation for a number of reasons which are partly cultural in nature. ${ }^{13}$ The Berle-Means type corporation has simply not developed as a common type to date. ${ }^{14}$

I now propose to examine some key elements of the Chinese family firm and 
weave in, where appropriate, relevant similarities and differences in mainland China since, post 1997, the influence of business practice and corporate governance between Hong Kong's SAR and China will increasingly become a two way traffic.

\section{Hong Kong's "Chinese family” corporations}

Before considering Hong Kong it is important to note that according to Kirby ${ }^{15}$ the history of company law in the first half of the twentieth century in China tends to show that the assumption of early reformers regarding the anonymous private corporation on a Western model as the essential means to "facilitate commerce and help industries", proved over optimistic. The record shows that with its own organisational structures and values rooted in networks of family and regional ties, what may be termed a "capitalism with Chinese characteristics" resisted the corporate structure even in the period of its dynamic growth in the first half of the twentieth century. However leery of government, China's capitalists appeared even more suspicious of the public, finding the idea that they would be invited to share in one's business's control and profits most dislikeable. ${ }^{16}$

A similar tendency is discernible in Hong Kong where Chinese businessmen initially rejected the partnership and corporate law imported from the UK, which they found quite alien, insisting on their Chinese partnership legal regime. Apart from the Western educated elite, ${ }^{17}$ only after the second world war did local Chinese businessmen take to using the corporate form as a legal vehicle for business activity. So successful has the adoption of this legal form been that almost two thirds of all business registrations today are registered in the name of corporate bodies. ${ }^{18}$

\section{The Legal Regime}

The Law of Hong Kong is primarily influenced by that of England and Wales and to a lesser extent by that of Australia. ${ }^{19}$ Hong Kong public companies, are in the main incorporated for a non commercial or quasi charitable purpose. ${ }^{20}$ Those which are of a purely commercial or business nature are usually listed and quite closely controlled, since the minimum percentage of equity securities which must be in public hands may be between $10 \%$ and $25 \%$ depending on the market value of the applicant, and this is only exceptionally exceeded. ${ }^{21}$ The vast majority of companies (both large and small) are private in nature. ${ }^{22}$ From approximately 2000 companies registered in 1948 the number has risen to 471,883 by December 1995 . To this must be added the increasing number of offshore incorporations which for political and fiscal reasons are often situated in tax havens such as the Bahamas or the British Virgin Islands. ${ }^{23}$ Indeed the majority of Hong Kong's listed companies have, post 1989, incorporated their ultimate holding companies offshore. ${ }^{24}$

Many public listed and private Hong Kong companies retain many of the characteristics of small scale family businesses, such as paternalism, personalism, opportunism and flexibility, even when conducting a very large scale of operations. They do not display the characteristics of separation of 
ownership and control, professionalisation, bureaucratisation and neutralisation to anywhere near the same extent as their Western equivalents. ${ }^{25}$

There are even more fundamental differences in Hong Kong in relation to the core nature of the Chinese controlled corporation. In the Chinese context personal connections or guangxi have remained a key element of Chinese organisation. Law was never really available in China as a practical recourse for the merchant, and without such a backing all relationships remained personalised. ${ }^{26}$ This in turn produced a barrier to the scale of enterprise, as important transactions would only be made face to face, and it made redundant any need for the professional executive who would rationally pursue goals on the part of others as part of a contractual exchange. ${ }^{27}$ As Faure points out, for a long period of Chinese history, lineage and family connections were, and were recognised to be, the most fundamental relationships in economic organisation, not only for consumption but also for production and trade. ${ }^{28}$ By placing a heavy emphasis on the family form of society, Confucianism sanctioned a family based economic system. ${ }^{29}$

In China "law" was traditionally an expression of the rule of heaven (tianli or tiandao) and from this concept came the idea of gongdao which may roughly be translated as "justice" and is a term usually used when people think that a result is unacceptable or unjust and that something should be done to put it right. In theory law should be in harmony with, or in case of contradiction subordinate to, "the people's feeling" (renquing) following the view that "the rule of heaven is great because it is in line with people's feelings". ${ }^{30}$ As the dominant school confucianism placed emphasis on "people's feeling" (renquing). Individuals are therefore more concerned about the feelings of those with whom closer personalistic ties (guanxi) exist. Since the family was conceived by Confucius as the basic social unit, family ties or feelings are strongest. From these basic units a network of class is formed and degrees of relationship with people from the same village or locality (tongxiang). ${ }^{31}$ As a general rule, the combined effects of this emphasis on "people's feeling" and confucianism are that the closer the relationship the better the treatment will be: generally family members should be trusted and treated best, secondly your clansmen, then friends and colleagues and those who live in the same village, bear the same surname ${ }^{32}$ or come from the same locality or province, and finally those who have no relationship with you. ${ }^{33}$ There remain however some metatheoretical issues in the study of Chinese social interaction one of which is that the distinction between ideology, "ideal culture", or "big traditions" and on the ground behaviour, "real culture", or "little traditions", is insufficiently drawn. This encourages an overly enthusiastic application of confucian precepts to modern chinese life. ${ }^{34}$

According to Hamilton ${ }^{35}$ one of the most successful attempts to envision the patterned differences between Western and Chinese societies is that of Fei Xiaotong originally published in $1947 .{ }^{36}$ Explaining the organisational and social psychological differences between China and the West, Fei uses two extended metaphors to explain the distinctive patterning in each society. Western society is compared to the way rice straw is gathered to build a haystack. Individuals obtain their identities from the organisation to which they belong or are affiliated to. These organisations have clearly defined boundaries. 
Organisations such as a club, or the office or a division of a corporation in which one works fit into other organisations, such as a city and so on, until the highest level subsuming organisation is reached. Fei believes this to be the Western state. In Hamilton's terms individuals fall under specific and distinct jurisdictions and take their rights and duties accordingly. Organisations from the club to the corporate workplace to the state legitimately constrain individual actions in separate but distinct ways. ${ }^{37}$

Chinese society in contrast does not build upon distinct basic social units. Fei demonstrates that even the Chinese family (jia) is not a clear social unit in the way it is in the West, but is ambiguous as to which relatives are included within this definition. The metaphor he uses for Chinese society is that of concentric rings flowing out from the centre when a stone is thrown into a lake. A Chinese person stands at the centre of the circles produced by his or her own social influence. The rings near the centre are those of kinship relations which are many and varied but they do take precedence over other more distant relationships as indicated above. Everyone's circles of influence or rings of relationship are interrelated, but no one person has exactly the same set. Unlike the clearly "organisational" jurisdictions in the West, Chinese relationships are ranked and the duties for each relationship are publicly known and to some extent codified. Fei suggests that individuals calculate their actions by knowing, not where they are organisationally, but rather by knowing with whom they are dealing and knowing the relationship that prevails.

Recent work on the role of personalistic relationships in China and the development of its new legal system has emphasised the continuing importance of such patterns of behaviour ${ }^{38}$ and these are often mirrored in the internal management function and decision making process of mainland enterprises even at board level. As Child observes of senior mainland managers:

The cultural tradition within which they work leads to an expectation that managers will attempt to accommodate the demands placed upon them through personal relations in which they endeavour to establish some tolerance based upon trust and negotiate in a relatively harmonious fashion some space within which to operate. ${ }^{39}$

In China the influence of renzhi and its direct counterpart guanxi inevitably lead to the "rule of the virtuous man", rather than the rule of law. However, renzhi often results in government by whim or caprice. There are numerous examples of this, which when combined with government and justice by guanxi, often lead to attempts to nullify the rules which do exist or pervert the course of justice. This is also reflected to some extent in Hong Kong. ${ }^{40}$ It has serious implications for regulatory compliance and enforcement.

\section{Culture and Governance}

The role of culture in the Hong Kong corporate governance context has also been examined by Tricker. He points out that the word "man" with all of its overtones of separateness, free will and individualism does not overlap in meaning with the Chinese word yan with all its overtones of connectedness and 
reciprocal relations. This has important implications for corporate governance. The original Western concept of the corporate entity creates a juristic person separate and distinct from its members. That juristic entity in law takes on the attributes of a person, a Western person. By way of contrast the Chinese perception of the nature of man as not being "separate" but connected and imbued with overtones of reciprocal relations "entails correspondingly different expectations of the corporate entity". ${ }^{41}$ There is no real separation between family and company interests and a resulting lack of clarity as to where corporate boundaries lie. Furthermore, the question has been posed whether, given the lack of abstracts in the Chinese language and underlying differences in thought processes, the basic abstract concepts necessary for the development of modern Western corporations, and not only the concept of "separate legal personality", but also "marketing function", "financial control" and "divisionalisation", are not just foreign but somehow unnatural to Chinese organisations. $^{42}$

Officials of Western origin in the Hong Kong Securities and Futures Commission (SFC) have expressed concern that the controllers of local listed companies sometimes fail to grasp the distinction between corporate and family property. ${ }^{43}$ Perhaps the real concern is that in importing Western corporate concepts regulators have failed to realise the significance of local culture and that the local perspective of and use of the corporate form is in some ways fundamentally different. The problem is exacerbated by the ambiguities of relationships in relation to property which is exemplified by the following quotes:

You have to understand a Chinese family. There is no difference between my father's personal investments versus my personal investments. Its one. It is called family investment and that is it. $^{44}$

And in contrast:

Capital accumulation is to keep the company running. That was my father's philosophy. It is not personal property. It belongs to all contributors, the staff included. ${ }^{45}$

The latter quote may be viewed in terms of a family estate not being personal property in the sense of belonging to an individual but as family property in the sense that the family estate is a business and the family is notionally extended to include loyal staff. ${ }^{46}$

This attitude to property may also be reflected in the patterns of corporate control. As Scott has commented:

Any comparative account of corporate control must recognise that while there are certain uniformities of technology and business practice in all of the major capitalist economies there are equally important divergencies arising from specific historical experiences and differing cultural and legal systems. These national variations shape the constraints which operate on the actions and orientation of business leaders and result in the 
existence of a number of alternative patterns of capitalist development. The pattern taken by impersonal possession in Britain, the USA, Australia, Canada and New Zealand is to be seen as the outcome of a specific convergence of national and international forces in the Anglo-American, English speaking world. In other parts of the world, and under the impact of other forces, different patterns of impersonal possession are apparent. $^{47}$

The separate juristic nature of the corporation and its economic counterpart the concept of personal property represented by shares in the corporation as distinct from industrial property represented by the property owned by the registered company does not fit well with the cultural milieu of the Chinese family firm.

Although the Western based legal business system in Hong Kong gave Chinese entrepreneurs a freedom of opportunity which they seized, it was adapted to their cultural context. ${ }^{48}$ Incorporation is used and limited liability welcomed, but the underlying nature of a Chinese family owned business has significant implications for a Western concept of corporate governance. Chinese family based organisations are described as being imbued with "patrimonialism", which includes features such as paternalism, hierarchy, responsibility, mutual obligation, family atmosphere, personalism and protectionism. Redding identifies three related themes which flow from these and are in some senses expressions of patrimonialism: the idea that power cannot really exist unless it is connected to ownership; a distinct style of benevolently autocratic leadership and personalised as opposed to neutral relations. ${ }^{49}$

A distinct and particularly Chinese organisational characteristic, viewed from a Western managerial perspective as a defect, arises because corporate power derives from ownership which is vested in a family rather than an individual. Nobody outside the owning group can generate for himself truly legitimate authority. Chinese family businesses are often unable to escape autocratic control because of a common inability to delegate and inherent mistrust (especially of professionals) makes it very difficult to graft into the organisation a middle and senior management group made up of competent professionals. ${ }^{50}$

Wong identifies various instances when a Chinese family business comes under breakup stresses. One of these is the third generation problem which clearly reflects a major difficulty in pushing a Chinese family business through a Western style managerial revolution to transfer power to professional executives and divorce, to some extent, ownership and control. ${ }^{51}$ Resistance to the competent non family executive remains strong and is potentially dangerous for him if he is perceived as a threat. Given the endemic leaning towards secrecy in Chinese family businesses, as in other aspects of life, simply knowing too much about the business could constitute such a threat. ${ }^{52}$ This has serious implications for any attempt to introduce non executive directors.

There are however Chinese corporations in south east Asia which have to some extent evolved beyond the concept of guanxi and developed non particularistic ties as a major factor in their business strategy, but they remain few and far between. ${ }^{53}$ Reliance on personal ties within and without the Chinese family firm 
give it the special advantages that enable it to be so successful in the context and on the terms in which it operates. Networks of external personal relationships and an autocratic span of control within allow the Chinese family business to prosper and respond to challenges such as, for example, the need to retool with almost acrobatic flexibility. The other side of the coin, however, relates to limitations on the growth in size of the business and potential break up stresses. When an organisation begins to grow the Chinese capacity for mistrust "begins to weaken the seams in the fabric". ${ }^{54}$ Companies do not cope well with the maintenance of control as they expand into new markets, new products and new technologies. In fact such challenges are often avoided and the vast majority of companies remain small. ${ }^{55}$

As regards the issue of maintaining control and venturing into large scale operations Redding identifies two possibilities, particularly in the context of Hong Kong. ${ }^{56}$ One route is to graft on professional management and build a conglomerate. Strategic thinking may still be retained by family members, while divisional operations are left in the hands of professional managers. According to Redding the few conglomerates that have emerged tend to suffer from power disputes dividing the professionals and the owning entrepreneurial strategists. This type of large operation remains very much the exception remarkable for their rarity. ${ }^{57}$

One company which might be regarded as an example of a relatively successful conglomerate is Hutchinson which is involved in property, shops and store chains such as "Watsons" and "Park and Shop" and general trading. The company was originally founded by a flamboyant Australian Douglas Clague. ${ }^{58}$ In the business recession of 1974 Hong Kong Bank invested in the company and obtained equity control, showing Clague the door. After turning the company around, the bank sold its controlling share to Li Ka Shing. He is one of the few Hong Kong entrepreneurs recognised for an ability to trust and delegate to professional management.

The alternative, more successful route is to choose a business or industry which has the following characteristics:

- (a)

large but relatively infrequent judgemental decisions, as for example in property;

- (b)

day to day operations which can be replicated using a standardised formula, and easily controlled or managed contractually, as for example in shipping or hotel management.

- (c)

financing which can be based in the headquarters city on an individual's reputation. 
In such a context to extend the influence of the key executive group or individual is much more feasible. Hong Kong examples of Chinese companies with these characteristics include Cheung Kong Holdings based on the skills of Mr Li Ka Shing and World Wide Shipping, based on the skills of the late Sir Y K Pao.

At this point it is perhaps important to note the role of banks in the development of these larger businesses. Wong has dispelled the view that overseas Chinese businesses do not use banks as a source of finance. ${ }^{59}$ Simple pragmatism dictates that they will when appropriate and business historians have extensively documented these relationships. ${ }^{60}$ The Hong Kong Bank, in particular played an important role in the development of a number of Hong Kong businesses particularly in times of crisis as indicated in the Hutchinson example referred to above. Their equity investments were often used in some of the boardroom struggles and intercompany rivalries, especially where these allowed the bank to tip the scales in favour of Hong Kong Chinese entrepreneurs of proven ability (eg Sir Y K Pao and Li Ka Shing) at the expense of older British companies which appeared to have lost their way or become overstretched. In this sense the bank fulfilled a politico-sociological as well as a financial function. At one point the bank held a half of Pao's shipping companies and a fifth of Hutchinson Whampoa and Eastern Asia Navigation as well as a quarter of Cathay Pacific Airways and almost half of the South China Morning Post. ${ }^{61}$ Banks have therefore played an important if not crucial role in relatively recent times, by means of equity investments, in the development and survival of Hong Kong's larger listed companies. Similarly, in earlier periods, networking in Chinese business was strongly characterised by internal banking in the sense that the banker would enter into businesses as a partner, and that he would do so in a wide range of businesses in the search of good returns and in order to spread his risk. ${ }^{62}$

\section{Vertical Cooperation, Meetings and Management style: The Problem of Governance and Control}

One of the perceived weaknesses of the strong paternalistic Confucian style of management is the limitation of the strong vertical cooperation which gives strength on a small scale of operation but is a source of inefficiency and failure in the context of large size and growth. The key question is how far one person's decision making can be stretched. There are examples of Western and Japanese CEOs who have extensive influence throughout their corporations but it may be emphasised that they establish a system and a culture which expresses their policies, and then other people can make large decisions within that framework. ${ }^{63}$ In the context of the Hong Kong Chinese corporation the issue is the extent of the authority of the paternalistic controller, that person's decision making, his or her direct involvement. Successful large organisations have devised a formula for gearing up on the strategic intelligence of the dominant individual. Examples from shipping and property have been referred to above. In other spheres particularly product markets this is more difficult because a greater variety of factors need to be considered and in such circumstances, a one man decision making process will eventually lead to inadequately informed and late decisions leading to decline in the fortunes of the business. 
Personalistic methods of control do have advantages in terms of internal transaction costs due to less paperwork and fewer formalities just as the external trust networks of personalistic social/business relationships lends to efficiency of transaction costs in economic exchanges. This is because transactions may be dealt with reliably and quickly by telephone or handshake or over dim sum whereas in a Western context they would require lawyers, contracts, guarantees, wide opinion seeking and investigation all accompanied by inevitable delay. ${ }^{64}$ Such an approach is mirrored in mainland China where foreign businessmen often complain bitterly about the delays associated with establishing such relationships and the shifting sands of Chinese negotiation tactics. $^{65}$

While in recent years delayering and re-engineering has eliminated much of middle management in listed corporations in the Western world, Chinese family controlled listed and unlisted corporations have relatively little middle management if only because management and strategic decisions are made at the highest levels of the corporation and executed by staff who report directly to the corporate "management person" (who will also often be CEO/MD) or management team. As a result these corporations rarely have retainers such as legal, accounting and marketing management save and except what may be characterised as support staff. $^{66}$

All of this has important implications for the role of meetings and the decision making process in governance structures. The Western format of the structured meeting with the occasional expression of differences of opinion is often viewed with anathema in a culture based on the avoidance of conflict, consensus and personalistic relations in the overall context of what is often an autocratic leadership or management system imbued with deference to authority. ${ }^{67}$

A perusal of the annual reports of many listed companies in Hong Kong will reveal the extent to which a large number of such companies farm out their compliance work to service companies and individuals who provide company secretarial services. ${ }^{68}$ Several years ago the Carrian affair was the subject of criminal proceedings. During those proceedings one of the senior partners of a leading law firm gave evidence to the effect that his company secretarial staff would prepare minutes of Carrian Group company meetings in one of three ways. These were either by having someone present (which he admitted was rare); or by asking the directors to recount what was discussed and decided; or by using their sense of imagination. ${ }^{69}$ This is indicative of the local style where decisions are made and then lawyers etc approached where appropriate. I have discussed the technical and often disastrous legal consequences of such decision making elsewhere with graphic Hong Kong case examples. ${ }^{70}$ Suffice it to say that it is a reflection of the reality of the Hong Kong situation, namely that its corporate law regime is often little more than the formal clothing for, what in substance remains, essentially a familiar and personalistic Chinese organisation.

In the view of one Western educated local management consultant, board meetings are hardly ever confrontational unless there is a serious breakdown in personal relationships. Where a difference of opinion on, for example, a 
proposed course of action exists, the parties will simply state their positions. There is no attempt to openly debate and resolve a conflict. A compromise will be reached or decision made behind the scenes without an open loss of face which is potentially damaging for both sides. ${ }^{71}$ This is not very different from the situation in the boardrooms of many UK listed companies according to the work of Hill. ${ }^{72}$ The evidence there is similar. The majority of executive directors prefer not to disagree openly in public. Disagreements are voiced privately.A board meeting is a decision making event not a debate. Any debate will usually have taken place prior to the meeting. It is therefore most likely that any cultural differences will impact at that earlier stage. The greater powerdistance relationship in Hong Kong Chinese society and, for example, differences in humour will affect the extent to which dissent is expressed as well as the manner and force with which it is done. ${ }^{73}$

Similar observations have been made in relation to the operation of boards of directors in Sino-Western joint ventures but with the importance of the impact of culture on this phenomenon emphasised. Björkman, notes that the risk of losing face, the tendency of the "superior" to talk for most of the time inhibiting input from directors and the need for permission from superiors before being able to support a board decision (which is difficult to obtain during a meeting) all militate against open debate and discussion in board meetings. Also, in the context of a joint venture, the trust and general relationship between the foreign partner and the Chinese is likely to deteriorate if they openly show that they have conflicting ideas. A failure to realise this on the part of the foreign partner has led to total deadlock at both board and operational level in the initial stages of several joint ventures. Later, several stages of consultation were adopted resulting in a smooth formal board meeting for which the minutes have often been written in advance. ${ }^{74}$

The Hong Kong scenario of an avoidance of structured meetings and a preference for unscheduled, unstructured meetings, cultivating informal personal contacts therefore appears to be even more accentuated in studies of mainland Chinese enterprises. Stewart suggests that one reason for this is the limited experience and competence of mainland Chinese managers in the use of formal scheduled meetings:

in the Western world schedule meetings as a communication medium have been fully developed and practised with sets of structured, formal and commonly accepted meeting procedures, and their actions in information dissemination and problem solving are well exploited. However, these procedures and functions are still somewhat lacking in China. Instead, the PRC managers tend to attach different values to attending scheduled meetings (cultivating interpersonal relationships, showing one's commitment, diligence and fishing for unsystematic information) but these aims are more easily achieved in unscheduled meetings. ${ }^{75}$

The traditional approach and its value to mainland Chinese managers is also emphasised by Stewart: 
the value of unscheduled meetings in the PRC is due to another factor. The importance of Guanxi, or personal connections, in China is well known ... The unscheduled meetings provide ways in which to cultivate valuable interpersonal relationships more easily than during formal occasions. Most managers interviewed stressed the need to develop and maintain good working relationships with colleagues and environmental contacts: they saw this as the chief factor in their career success. ${ }^{76}$

Child also makes similar and forceful points concerning the conduct of high level scheduled meetings in China:

It is rare for such meetings to have a formal agenda or for papers to be presented to members in advance. Discussion defers very much to the most senior person present, who is generally more concerned to establish a climate of consensus around general principles or directions of policy than to raise specific issues. His or her approach looks to securing agreement on these general lines, which can then serve as the justification for arrangements and deals that are later struck through informal personal discussions. The outcome of these meetings is sometimes left so vague that it is not even clear what has been agreed. Normally, no minutes are taken though various clerks will take copious notes which are then filed away primarily to protect the heads of their departments or units should any dispute or criticism later arise. This means that follow up action has to be initiated personally by the senior manager and that the next meeting does not necessarily review progress on any systematic basis. It all reinforces the ever continuing need of Chinese senior managers, and directors in particular, to deal with matters on a personal basis. $^{77}$

Child goes on to pose the question whether Chinese senior managers' reluctance to delegate and their inclination to handle matters personally can be viewed as a response to the system of industrial governance within which they operate (particularly the power structure and informational environment), to the competencies at their disposal, or to their cultural context. ${ }^{78}$ It is reasonable to assume that the cultural characteristics discussed earlier will reinforce the hierarchical top down command structure that China's economy acquired under socialism and from which it is slowly retreating. ${ }^{79}$

One might step back at this point and contrast the approach in the UK, for long the model of Hong Kong's Corporate legal regime and governance system. As Charkham points out, boards of UK quoted companies take meetings seriously and this is reflected by Hill. ${ }^{80}$ However, "any chairman can 'fix' the composition of the board or the agenda or the information or the meeting. It is no wonder that two boards with identical structures may be quite different in their effectiveness. It is the possibility of such extreme variation that underlines the importance of the role of the non executive directors and ... requires the active vigilance of the shareholders." 81 Charkham's acid test of the effectiveness of 
non executive directors is the "say 'No' test". ${ }^{82}$ In the consensus and high power-distance context of Hong Kong Chinese firms this poses serious problems, but as Charkham points out the test is not as negative as it sounds because it is based on the important principle, in a Western context, of reciprocal respect. If a CEO and the board do not respect each other the system will not work as it should. Failing this acid test means that boards are not boards at all but merely advisory committees. This poses serious questions concerning the recent Hong Kong Stock Exchange introduction of a requirement for listed companies to appoint independent non executive directors.

\section{The cultural aspects of interlocking directorships and their impact on the introduction of non executive directors in Hong Kong}

I have briefly examined the introduction and role of independent non executive directors (NEDs) in Hong Kong in the context of directors' remuneration in an earlier volume of this journal. $^{83} \mathrm{I}$ now, wish to re-examine that issue emphasising the cultural aspects of interlocking directorships and the implications for independent NEDs in Hong Kong.

The significance of interlocking directorships has been interpreted in the context of several models, each postulating distinct mechanisms and processes in the exercise of economic power. There are also a number of contending perspectives often associated with rival political positions. ${ }^{84}$ However, the fundamental question remains, irrespective of the perspective or position within which interlock researchers work, namely what does an interlocking directorship signify? Scott asserts that the majority of researchers have gradually come to realise that interlocks are most usefully treated as indicators of social relations. ${ }^{85}$ Given the importance of social and personal relations in the Hong Kong business context the introduction of independent NEDs was bound to meet with some resistance.

In fact many listed companies had problems complying with the deadline. At an executive conference organised by HKICSA, Mr Keniel Wong a director of the HKSE listing division stated in his speech that as of 1 December 1994, one month before the deadline for the appointment of the second NED, 6 listed companies had not yet appointed their first NED and over 100 had not appointed their second. The deadline was subsequently extended by 3 months. ${ }^{86}$ This is not surprising. The work of Gilbert Wong on interlocking directorships in Hong Kong demonstrates a distinctive interlocking behaviour in the nature of Chinese firms in Hong Kong. His research demonstrates that the ownership and control of the top 100 largest corporations in Hong Kong has actually become more concentrated and personalised in recent years and more of the boards were controlled by family members of the major shareholders. Many characteristics of the traditional small Chinese family firms were brought into large corporations which were once controlled by British owners and managements. Given the high degree of personalism in the management of Chinese family businesses, inter corporate relationships became more personal and informal. According to Wong, formal business networking ties in the form of outside directors appointed to created corporate interlocks, is not a major ingredient in 
the Chinese business recipe. When Chinese business relationships are often based on personal trust it may well be regarded as an affront to the integrity of the businessmen concerned to force them to accept the Western method of using outside directors to safeguard investment interests.

In this context of listed companies characterised by concentrated ownership relying on personalised trust and control the emphasis is on the use of multiple executive directorships. This fosters an inward orientation based an inter corporate relationships generally limited to the in group of businesses which are possessed of strong associations with each other based on ownership ties, family and other traditional linkages. According to Wong therefore:

The intense and personal commitment of executive directors to the family firms also means that it would be unlikely for other business to invite them to serve as non executive directors. Their independence, in the context of the competitive environment of Hong Kong, would be questionable. In this situation, directorate linkages, if required at all, will be effected through outsiders who are not executives of either of the connected businesses. In consequence, executive and non executive directors take up different roles in the Chinese businesses and this leads to a sharper differentiation in the roles of the strong and weak ties in the interlocking directorates. ${ }^{87}$

Wong emphasises the importance of the cultural factor in shaping business behaviour in Hong Kong and highlights the limitations of applying "Western" theoretical models straightforwardly in the Asian societal context. Therefore the configuration of directorates ties, must be explicated in the context of the social culture in which they are found irrespective of whether they follow resource interdependence, ownership, family relation or some other social and economic pathway.

The emphasis in both the Cadbury and Bosch reports tends to be on the monitoring role of executive directors. A polarisation of attitudes between family executive directors and NEDs may well result from such an approach in the context of the Chinese family dominated listed company. As Redding observes: "The grafting on of new outsiders at a senior level in such organisations is particularly difficult, given the lengthy socialisation needed for understanding the organisation's core and often concealed features, but more particularly given the problem of time needed for the essential networking, not just outside but also inside the company." ${ }^{, 8}$ Although NEDs are not executive managers or directors in the personalistic context of Hong Kong they must be, acceptable to the "governing" family and gain their trust. This will erode their independence and capacity to say "No". Problems have emerged of access to information and the use of informal channels upsetting the delicate relationship of trust, confidence, and in the words of Charkham "reciprocal respect" that must exist between a managing director and the board. It has been reported that in one Hong Kong listed company non executive directors are allowed to see relevant papers at the start of board meetings and have them taken away at the end. ${ }^{89}$ This reflects the initial lack of trust which may well arise in the context of a Chinese family controlled listed company when they are forced to accept 
relative outsiders. Yet issues of confidentiality if not secrecy are also of importance in the Western context. All directors whether executive, nominee executive or non executive, and independent NEDs owe a duty of confidentiality to the board and case law has confirmed this. ${ }^{90}$ Indeed the report of the UK Committee of Public Accounts on the role and responsibilities of nominee directors emphasised that nominee directors could not assist government departments and non departmental public bodies directly in the monitoring process, or pass confidential company information to them, without the prior agreement of companies or unless special arrangements such as contractual conditions of financial assistance permitted them to do so. ${ }^{91}$

Perhaps the better approach to boards as whole, is that of the Hilmer Committee's "Strictly Boardroom". That emphasises the theme that formal rules which are imposed on boards to ensure conformance with external requirements, must not be allowed to prevent directors from achieving the main goal which boards must serve. The boards key role is defined as ensuring that corporate management is continuously and effectively striving for above average performance taking account of risk. ${ }^{92}$ This does not deny the boards additional role with respect to shareholder protection. In relation to strategy and policy, Hilmer felt that the board of a large public company is an inappropriate body for developing strategy, setting corporate culture and policy and initiating major decisions. Instead the board should concentrate on the critical review of proposals, with management having the primary duty to formulate and then implement proposals. ${ }^{93}$ NEDs should concentrate on keeping the board's primary performance responsibility at the top of the agenda. Such an approach may be received more positively in Hong Kong and would certainly leave the controlling family heads free to devise strategy and policy. The problem of allowing that strategy to be reviewed by relative outsiders would however remain difficult to surmount.

Non executive directors have recently played a key role in the removal of members of a founding family from the board of a listed property developer, Keng Fong Sin Kee Construction \& Investment Co after perceived abuses on their part. The managing director was quoted as saying "Having two independent non executive directors on the board is the best thing the stock exchange has done in the market". In that case it was other members of the extended family which voted the directors out of office. Where the situation is one of a united controlling family versus the investing public the task of NEDs may not be so easy. ${ }^{94}$

One issue which over time may prove of significance is the increase in and demand for well educated and professionally trained managers.In recent years Hong Kong has expanded its tertiary education sector and courses in business studies and related fields have mushroomed in response to a high level of demand. ${ }^{95}$ Much the same has happened in the context of legal studies. A similar phenomenon has occurred in China with the demand for trained management not only in the state sector but in the ever increasing number of joint venture projects in China. A large number of mainland Chinese are increasingly opting for business and management studies particularly in the USA. $^{96}$ The extent to which this will influence business, management and to some extent corporate governance practices in future remains to be seen. One 
important aspect is the cross cultural influence of joint ventures in both Hong Kong and China. I will now turn to a brief consideration of this issue.

\section{The impact of joint ventures on management and governance style}

There are many examples in Hong Kong of equity joint ventures between Western companies, with a desire to manufacture and sell in Southeast Asia Region and local Chinese companies with extensive distribution networks throughout the region. ${ }^{97}$ Mainland China has also encouraged the growth of numerous joint ventures with Western, Japanese, Hong Kong and Taiwanese business in its bid to develop its economy. Indeed, the development of China Post 1979 owes much to the overseas Chinese Diaspora.

In both contexts, as explained above, the Hong Kong and Chinese manager has been imbued with a different system of management norms which are even more marked in the mainland Chinese context because of the political economic system. As Child points out, in the mainland context these differences create problems of mutual comprehension and present both sides with the need for considerable adjustment and learning. ${ }^{98}$ Joint ventures also have other problems. They are often regarded as second best compared to wholly owned subsidiaries because of concern over the limits to the control that a parent company can exercise.As Schaan points out, they have all the control problems of subsidiaries plus those which arise from joint ownership. ${ }^{99}$ But in the context of South East Asia and China the need to tap into the existing personalistic business networks of a joint venture partner is immediate, for otherwise a Western company may spend years building up the same trust relationships and a competitor who taps into those of a joint venture partner has a considerable advantage. According to Child both partners are bringing complementary strengths to the joint ventures. In order to realise these an agreed basis of cooperation must be found. Even the holding of a majority equity position cannot be used to enforce control over the venture without jeopardising the basis for its success. Therefore some limitation of control is the price to be paid for securing the advantages of a joint venture. ${ }^{100}$

The evidence from joint ventures on changes in management and boardroom practices introduced by foreign parties identifies the different approaches of the various foreign partners and discerns the modes by which foreign and Chinese managers relate and adjust to each other. Some of these have already been referred to in the context of board meetings. ${ }^{101}$

American and European companies tend to introduce formalised systems for transmitting key information and for defining the framework of managerial authority and responsibility. This helps to clarify managerial roles and obligations while at the same time establishing a framework within which operational decisions could potentially be delegated and responsibility for those decisions be clearly identified. ${ }^{102}$ When this is combined with substantial management training programmes evidence from longer established joint ventures suggests that after a while local managers, at least on the mainland, develop to the point where the foreign partner is confident about delegating responsibility to them. However, in this context it is important to note that the 
American joint ventures in particular tended to recruit the most highly educated workforce. ${ }^{103}$

Formalisation is found to be much less developed in the Japanese and Hong Kong partnered ventures. The approach among the latter was to control through personal intervention while the Japanese, as one Japanese vice chairman of a Shanghai venture put it, "want to change their minds". They attempt, not wholly successfully, to fashion Chinese work behaviour through creating organisational cultures with strong collective norms. ${ }^{104}$ American joint venture partners tend also to push for change more aggressively, but do not require so much a re-culturalisation as an understanding of how to conduct business and to use the modern techniques associated with this although they sometimes fail to give their local colleagues much opportunity to get involved in the strategic process. ${ }^{105}$ In this context, however, it is important to note Child's point that when Chinese managers hold a different orientation this is not necessary born out of a poor strategic understanding but is rather founded upon a realistic perception of different interests between partners: it is inextricably bound up with the issue of control. ${ }^{106}$

A second issue becomes relevant here namely that when "forced" to adopt new methods or practices the behaviour of the Chinese may be modified but the reasoning behind the changes they are obliged to accept is not internalised. ${ }^{107}$ The extent to which Western organisational norms influence behaviour, particularly in relation to the issue of open discussions, delegation and questions of control is debatable. With the advent of organisational behaviour texts which emphasise the South East Asian context the cultural tendencies of managers and directors of future Hong Kong companies are arguably being reinforced rather than diluted by Western style training. ${ }^{108}$ The cultural implications for the internal organisation and style of corporate governance of Chinese family controlled businesses remains therefore an important part of the equation which, if ignored in any corporate law reform, will be ignored at the peril of that reforms success including any reform relating to securities markets, control and accountability and transparency. With this in mind I now wish to explore some cultural aspects and Wong Sui Lin's Model of the Chinese family firm, its life cycle and the possible separation of ownership and control.

\section{Some cultural and psychological insights}

The importance of "national" cultural traits and their impact on organisational behaviour has been emphasised by the work, inter alia, of Hofstede ${ }^{109}$ and more recently Trompenaars. ${ }^{110}$ I will refer briefly to some of the factors identified by these and other writers which may prove relevant to the corporate governance issues as well as the expanding research in the field of Chinese psychology. The two elements which I wish to draw attention to here are those of power distance and uncertainty avoidance.

Although there are some similarities between British social hierarchies and those of the Hong Kong Chinese one major difference is in their"power distance score". ${ }^{111}$ According to some writers there is little remaining today beyond lip service to Confucian thought in Chinese behaviour except in 
hierarchial authority and power. ${ }^{112}$ According to Hofstede and Trompenaars the Chinese (including Hong Kong) have a much higher power distance score than the British. In large power distance countries there is considerable dependence by subordinates on bosses. The response of subordinates is either to prefer an autocratic or paternalistic boss ie accepting or preferring dependence, or to reject it entirely. The latter is called counterdependance (in psychology a form of dependence with a negative sign). In both cases, the emotional distance between bosses and their subordinates is large: subordinates are unlikely to approach and contradict their bosses directly. This factor when combined with the other cultural elements referred to earlier has a significant impact on decision making, for example, within the cultural context of high power distance, Chinese managers are likely to spend much more of their time with their superiors and much less of it with outsiders and their peers than say American or British managers. ${ }^{113}$

It is likely that Chinese directors/managers give more orders and spend more time checking on their implementation than do their Western counterparts. Similarly, making short term decisions involves senior directors/managers much more in China than it does for example in the UK, whereas in the case of long term decisions, the pattern is often reversed. Substantially different results have been observed in different economic sectors for example manufacturing as compared to service industries. This underlines many findings that effective leadership behaviours are not dependant solely on cultural issues, but are driven by an interaction between culture and the logic of each organisation's commercial and political environment. ${ }^{114}$ To the latter might be added its legal and regulatory regime. There are, of course, numerous other aspects of a large power distance factor and its impact and interaction with other elements both cultural and non cultural. In particular the interaction with "in group" (including the family) and "out group" relationships, assertiveness ${ }^{115}$ and decision making in high and low risk contexts. ${ }^{116}$

A lower uncertainty avoidance score for Hong Kong and Singapore Chinese is in some aspects difficult to explain. ${ }^{117}$ The scores for Taiwan for example are much higher. ${ }^{118}$ But both the British and Hong Kong scores are relatively low. This ability to accept and deal with ambiguity in both cultures may provide some answers for the successful adoption of the UK corporate form in Hong Kong.

A corporation is no less an invention than a steam engine. It is an institutional invention developed in a particular historical and cultural context. Therefore, it may take considerably more time for businessmen from another culture to appreciate its advantages whereas those of a steam engine are more obvious. ${ }^{119}$ According to Faure, the Chinese have their own very clear ideas of corporations which are described by a wide range of terms for which translation is often at best approximate. Nevertheless, the Chinese concept, whether voluntary or not gave the appearance that its existence extended beyond the individual and allowed for the illusion that property rights could be maintained for generations if not perpetuity. ${ }^{120}$ However, by the latter part of the nineteenth century merchants conducting business on the China coast and South East Asia were served in part by sophisticated institution that had their origins outside China particularly Western banks, shipping and insurance companies. ${ }^{121}$ Over the 
years that followed and increasingly after the second world war those institutions were used by the Hong Kong Chinese merchants themselves but adopted to the context of their business culture. ${ }^{122}$ That context was the Chinese family firm with its extended business networks.

\section{The Chinese family firm and its lifecycle}

According to Wong in order to understand the characteristics of a Chinese family firm it is important to identify the stage of its development and the social dynamics involved at each stage. ${ }^{123} \mathrm{He}$ identifies four important stages, the emergent, centralised, segmented and disintegrative. The emergent stage may be bypassed where an entrepreneur has sufficient capital, but as Wong points out many corporate businesses, eg textiles and banks, do not start simply as a family concern "because it is unlikely that the funds mastered by an individual and his jia (family estate) alone are sufficient to set up an enterprise other than a very modest one". ${ }^{24}$ Where "partnerships" are used albeit in corporate form jockeying for control will occur and an asymmetrical growth in the distribution of shares. Similar evidence is provided by Suehiro in relation to Chinese firms in Thailand ${ }^{125}$ and by Hattori in relation to family control of Chaebol in Korea. ${ }^{126}$

Eventually, a shareholder and his jia ultimately attain majority ownership. In the centralised stage, the managerial and structural aspects of which have been considered earlier, profits are often used to finance expansion which may also include transfer of assets from one line of business to another for lateral expansion and mutual sustenance. Capital is mobile within the family group of businesses because it belongs to a common unified family budget. Although the father entrepreneur has absolute authority in utilising the capital of the family firm it is not his person property. He is almost, in Western terms, a trustee of the family estate which belongs to his children. The more he enriches that endowment the greater his social recognition. This can often lead to a tug of war between the father entrepreneur and sons inheritors which usually drags on while the father tries to contain the centripetal tendency of his sons and maintain his social recognition. ${ }^{127}$

After the demise of the father entrepreneur the firm enters the segmented stage. Unlike land which must be divided equally between inheritors a business is more amenable to surviving intact in the later phases of the centralised stage and early phases of the segmented stage because profits can be shared. Also the typical restrictions in a private company's constitution on the transfer of shares such as a pre-emption clause or directors' discretion to register transferee as members help to contain the business intact as a family business. The likelihood of splintering the estate of the family firm at this stage is not great. ${ }^{128}$

The situation as regards management and control is however different. Brothers may attempt to foster their own distinct spheres of influence and consensus among them cannot be taken for granted which curtails the power of the chief executive. This in turn gives rise to characteristics of outward expansion of the enterprise owing to segmentation, and a reduction in the flexibility for reinvestment and risk taking as the CEO increasingly takes on the role of 
caretaker of the family estate instead of innovator. There is some similarity with the emergent stage and one of the brothers, if not the CEO, may take over the business securing control for his family unit or fang. Otherwise there is an increasing tendency to split. ${ }^{129}$ The latter is accentuated in the third "disintegrative" stage. Brothers' sons, ie first cousins have more divergent interests because unlike their fathers, who begin on an equal footing as regards inheritance of shares in the family company, they will not have equal shares because of different fertility among various fang. This third generation situation leads to less identification with the original family business for economic and personal reasons and therefore to a greater potential for fission. ${ }^{130}$ Redding has also emphasised that even at this stage there is unwillingness to rely on outside professional management. ${ }^{131}$

Before leaving the life cycle of the Chinese family firm one other sociological element needs to be considered which is not dealt with directly by either Wong or Redding. The stages in the development of the Chinese family firm may well be mirrored in Western firms. The case law on minority shareholder protection in the UK has many examples of breakdowns in relationships between partners, eg Re Westbourne Galleries $\operatorname{Ltd}^{132}$ and Re Cummana ${ }^{133}$ and between fathers and sons as in Re H R Harmer $\operatorname{Ltd}^{134}$ or even brothers or other inheritors of the family business such as Re Cuthbert Cooper $\operatorname{Ltd}^{135}$ and Clemens v Clemens \& Sons Ltd. ${ }^{136}$ But in the context of the Chinese family firm and the important role of the family estate the concubine or second and even third wife can, and often does have, an additional disintegrative effect, just as extended polygamous business families also have inherent strengths. ${ }^{137}$

Many wealthier, and some not so wealthy, Chinese businessman take several wives or concubines. The practice of taking more than one wife was made illegal in Hong Kong in 1971. ${ }^{138}$ That does not stop the practice continuing on a more informal basis. One current social problem in Hong Kong is the practice, for example, of taking a second wife or mistress on the mainland by the increasing number of businessmen and managers or lorry drivers who spend a significant amount of their working time there. ${ }^{139}$

Concubinage was fairly well sanctioned in Chinese culture by the need to have male descendants. ${ }^{140}$ The practice often led to greater opportunity for discord and disjunctions. The acquisition of concubines as an outlet for sexual desires and a source of affectional response gave concubines the opportunity to take advantage of their primacy in the affection of the husband. ${ }^{141}$ They could exercise considerable informal power in the family; so much so that one late Ming dynasty lineage rules from the Miu lineage in Guangdong province had the following to say on the matter:

Taking concubines in order to beget heirs should be a last resort, for the sons of the legal wife and the sons of the concubine are never of one mind, causing innumerable conflicts between half brothers. If the parents are in the least partial, problems will multiply, creating misfortunes in later generations. Since families have been ruined because of this, it should often not be taken lightly. ${ }^{142}$ 
This has been reflected in some recent case law in Hong Kong where the sons of the first wife have attempted to disinherit the children of concubines. ${ }^{143}$ Similarly, although Hong Kong's minority shareholder law is very similar to that of the UK's there are relatively few minority shareholder cases which get to court, either at an interlocutory stage or for a full hearing. ${ }^{144}$ Many more writs are however issued. ${ }^{145}$ These are currently under investigation by a research project in my department which, although in its early stages, does indicate that splits in Chinese family businesses often involve disputes between concubines and their children on the one hand and the children of the first wife on the other, often at the segmented stage of a family business' development. One Barrister for example, who had dealt with seven such cases in the last four years, all of which settled out of court, confirmed that in two of them the disputes involved concubine scenarios.

One case which did get to court is Re Shiu Fook Ltd. ${ }^{146}$ In that case a concubine argued for just and equitable winding up on the basis of deadlock with the son of the first wife. There was evidence that she desired to emigrate to Australia and take part of the family estate with her. She failed to establish deadlock on the facts or that she had acted reasonably in not pursuing alternative remedies such as appointing more impartial directors, offering to sell her shares or pursuing an unfair prejudice remedy. The court emphasised the nature of the family business as part of the family estate and the inappropriateness of the remedy sought in the circumstances.

The factor of polygamy is clearly an important element which has to be taken into account in any model of the Chinese family firm because it affects the dynamics of the relationships between mother and sons and groups of syblings. These are some of the factors which Wong has recently considered but without reference to polygamy. ${ }^{147}$ Although this practice may be on the decline in Hong Kong it is clearly alive and well elsewhere, such as Thailand. ${ }^{148}$ But the effects of these relationship is felt today both in the success of "interrelated" networks of associated companies driven by a desire to maintain and increase their family wealth and the occasional disintegration of companies or their controlling constellations of shareholders when extended polygamous family relationships break down.

In the UK context Charkham emphasises the double ancestry of listed companies. One type the classic joint stock company had separation of ownership and control from its very inception. The other is the registered company which after Salomon v Salomon \& Co $\mathrm{Ltd}^{149}$ was often used as a family business vehicle with owner managers. According to Charkham:

Such businesses often stayed private for a long while, and either $\operatorname{died}^{150}$ or were absorbed. Of the successful a relative few were floated later; even so, they retained most of the characteristics of the family business with few if any outsiders on the board. Many of them, if truth be told, made the transition without changing habits, in the mistaken belief that it was they, the proprietors, who were conferring a favour on those who subscribe for some shares in their business, an error which occasionally persists. ${ }^{151}$ 
This double ancestry is reflected in the way people think about boards and the role of directors. A world of difference exists between a committee of owner managers in a private company (and by analogy a Chinese family dominated HKSE listed company) and a board of a great public company on which no one owns a significant shareholding. The question is whether it is appropriate to use the same legal and/or corporate governance regime for both.

\section{Conclusion}

In some ways the Chinese family corporation may be likened to a jungle in which firms live and die relatively rapidly or split into smaller organisms."Plants die but the Jungle keeps going on". The underlying fundamental elements of its inner core are unstable at a larger scale and in the second or third generations. The holistic way in which the family estate is inextricably identified as the corporate business renders regulation and governance problematic, even more so as the legitimacy of the power structure breaks down over time, without modern management structures or personnel to bridge the gap.

Hwang has argued, in a view markedly different from that of Redding, that a fragmentation of family business is not the only future that can be imagined. While Confucian family centred work values may guide small businesses, there are other long established systems of values upon which managers of expanding businesses may rely. Legalisation is identified as such a system which he defines in terms of the rights of the individual and equitable reward for individual effort. He concludes from his study of Taiwanese organisations that Chinese organisations become more effective only as they move away from structures reliant upon traditional Confucian values and toward structures based upon a more overt rationality. ${ }^{152}$ There is also considerable evidence in the early development of the overseas Chinese Kongsi of an attempt to develop a kind of civil society with elected officials and other institutions when Chinese businessmen were without state and family. ${ }^{153}$

The HKSE and SFC will have to tread carefully, lest many more companies, tiring of what is often perceived as an increasingly alien and intrusive regulatory regime, opt for privatisation. ${ }^{154}$ That is not to say that they should be less rigorous in enforcement but rather more subtle. Introducing the independent NED regime was an interesting development, particularly in the light of the sometimes easy going enforcement of the listing rules combined with the occasional cat and mouse game with those companies who are reluctant to comply. Herbet Hui's recent public statement that he was considering beefing up the guidelines on directors' resignation announcements to make the reasons for withdrawal from the boards of listed companies public was just one example of this. ${ }^{155}$ But the whole scenario is indicative of the underlying problems outlined in this paper. Hong Kong has its corporate cowboys ${ }^{156}$ and directors who attempt to pay themselves excessive remuneration ${ }^{157}$ or bigger listed companies by selling assets to them at huge overvalues $^{158}$ as do other economies to a greater or lesser extent. Secrecy is endemic and the Securities (Disclosure of Interests) Ordinance 1988 has only 
chipped away at the surface since non director substantial shareholders do not have to make disclosure in respect of shares held under a discretionary trust which becomes a new instrument in maintaining family cohesion in the centralised and early segmented stages of a family firm's life.

Hong Kong does not have the luxury like the UK, of a real dual root to the origins of its listed companies, except for a few examples like Hong Kong Bank, the majority of its listed companies commenced life as private companies (discounting the recent listing of mainland enterprises). Not just private companies but Chinese family firms. As listed companies they are potentially unstable within a few years or generations of the founder's death. The problems of boards and governance are more acute. A legal and corporate governance regime needs to be explored which readily allows a synthesis of the strategic options available to such firms for longer term survival, namely, a series of strategic alliances with Japanese or Western companies with advanced technology and international brand names or alternatively the slow but sure rationalisation, professionalisation and bureaucratisation of control with the professional staff to make it work.

As Faure has recently put it:

Established for the purpose of business, the enterprise can break away from family ownership and management, even though it does not always do so. Where it intersects with the financial market, however, the demands of the financial market tend to leave their marks on the business: the market demands accountability of the chief executive and some transparency in their managerial decisions. These demands do not mean that the chief executive cannot pass his position to his offspring, but it does mean that even if he does, his offspring no longer runs an enterprise that portrays itself as a family. ${ }^{159}$

But even if this is the case the factors outlined in this paper indicate that there are important differences in cultural outlook and expectations which affect the local response to the regulatory regime.

In the forthcoming review of Hong Kong's corporate law regime Ermano Pascutto proposes to draw upon a variety of corporate law models, mostly common law based, for the purpose of determining a Companies Ordinance for the 21 st century. In his inception report Pascutto emphasises that the UK model of corporate law, often the inspiration for Hong Kong's regime, may not be the way of the future. He quotes Gower: ${ }^{160}$

The major questions still unresolved, and likely to remain unresolved, can really be reduced to one: Has our system of Company Law (evolved in the 19th Century) adapted itself adequately to the needs of the 20th and the likely challenges of the 21 st. To suggest that it has not, may seem churlish ... (O)ur system of Company Law was, until recently, the model widely followed in the Common Law countries. That leading role has now been taken over by the United States (influencing Canada, Australia and New Zealand) and we cannot hope to recover it. 
Pascutto's inception report goes on to emphasise the influence of the United States and in recent times that of the Canadian system on recent reforms in New Zealand. Australian legislation is dismissed for its complexity and its failure to clearly distinguish between securities law matters and company law. It is regarded as "outdated and dense in form". ${ }^{161}$ Australian corporate legislation is currently going through a process of simplification. In regard to the Asian context the inception report states:

In conducting the review, reference should be had to the commercial and economic context in which the Companies Ordinance operates. Developments in companies legislation in other parts of Asia (where similar economic forces are at work) could be instructive. For example, Singapore and Malaysia currently have legislation in place modelled on the UK Companies Act 1948 and the Australian Uniform Companies Act 1961. Any plans for reform of these statutes would be of interest. Finally, any review of the Companies Ordinance must be done with an awareness of the recently enacted Company Law of the People's Republic of China. ${ }^{162}$

This, with respect, emphasises economic forces and fails to give due weight to, inter alia, the role of culture in the organisation, structure and management of Hong Kong companies. It is submitted that this is a serious oversight.

\footnotetext{
* Associate Professor of Law, City University of Hong Kong

1 M J Roe, "A Political Theory of American Corporate Finance", (1991) 91 Colum L Rev10; M J Roe, "Political and Legal Restraints on Ownership and Control of Public Companies", (1990) 27 J Fin Econ 7. M J Roe, Strong Managers Weak Owners: The Political Roots of American Corporate Finance, Princeton University Press 1994.
}

2 Roe, supra, n 1, Strong Managers Weak Owners, at 53.

3 M J Roe, "Some Differences in Corporate Structure in Germany, Japan, and the United States", (1993) 102 Yale Law Journal 1927 at 1929.

4 J Charkham, Keeping Good Company: A Study of Corporate Governance in Five Countries, Clarendon Press Oxford (1994) at 1-2, 249; Roe supra, n 3 at 1929.

5 This viewpoint seeks to explain the growth and strength of family business in Asia by focusing on family structure and affiliation networks. It opposes the joint stock company control concept (which presumes a linear type growth and expansion of enterprise organisation) insisting that the family business is not an early capitalist management form that will necessarily wither away in the midst of the advance of a modern joint stock company system but that the Asian, particularly the Chinese family business, has a rationality all its own: of A Suehiro, "Family Business Reassessed: Corporate Structure and Late Starting Industrialisation in Thailand", (1993) 31 The Developing Economies 378 at 380.

6 Business Roundtable, "Corporate Governance and American Competitiveness" (1990) 46 Bus Law 241, 242-3; Charkham, n 4 at 1 cf $n 1$ supra.

7 R J Gilson and M J Roe, "Understanding the Japanese Kieretsu: Overlaps Between Corporate Governance and Industrial Organisation", (1993) 102 Yale Law Journal 871.

8 R Romano, "A Cautionary Note on Drawing Lessons from Comparative Corporate law", (1993) 102 Yale Law Journal 2021; J M Ramseyer, "Columbian Cartel Launches Bid for Japanese Firms", (1993) 102 Yale Law Journal 2005. 
$9 \mathrm{~J}$ Edwards and K Fischer, Banks, Finance and Investment in Germany, Cambridge University Press, 1994. A new law has recently been proposed which will eliminate German Banks' most powerful weapon at companies' annual general meetings: their right to cast proxy votes for other investors whose shares they manage. In future, German bankers will need explicit consent from clients to vote their shares, making it harder for them to use the proxies for their own ends, see "Banks and Industry Unburdening", The Economist 20 July 1996, at 67.

10 Ibid at 6.

11 S G Redding, The Spirit of Chinese Capitalism, Walter de Gruyter, Berlin, New York, 1993 at 216.

12 Ibid at 213, 221; S L Wong, "Chinese Entrepreneurs and Business Trust", Business Networks and Economic Development in East and Southeast Asia, ed G Hamilton, Centre of Asian Studies University of Hong Kong, 1991; C Tseng, "Uncovering the Asian Web", World Executive Digest, July 1996, 25-46.

13 S L Wong, "The Chinese Family Firm: A Model" (1985) 36 The British Journal of Sociology 58 at 67. Redding, supra, $\mathrm{n} 11$ at 106-7, 178 and 216. See generally S L Wong, Emigrant Entrepreneurs, OUP, Hong Kong, 1988; V F S Sit, R D Cremer and S L Wong, Entrepreneurs and Enterprises in Macau, Hong Kong University Press, 1991.

14 The evidence that the managerial thesis of a separation of ownership and control as a corporation grows applies to, for example Britain and the USA, is at best tendentious, contrast the findings of E S Herman, Corporate Control, Corporate Power (1981), Cambridge University Press, New York, 1981 with those of P H Burch, The Managerial Revolution Reassessed: Family Control in American Large Corporations, Lexington Books, Lexington Mass, 1972 in relation to the USA; and P S Florence, Ownership, Control and Success of Large Companies, Sweet and Maxwell, London, 1961 with J P Scott, "Corporate Control and Corporate Rule: Britain in an International Perspective" (1990) 41 British Journal of Sociology 351.

15 W C Kirby, "China Unincorporated: Company Law and Business Enterprise in Twentieth Century China" (1995) 54 Journal of Asian Studies 43.

$16 \mathrm{Li}$ Chun, "The King-SSu-Uy of 1904 and the Modernisation of Chinese Company Law" (1974) 10 Chengchi University Legal Review, 17-21, continued (1974) 11 ibid at 163-209.

17 Research on the Japanese re-registration of companies during the Japanese occupation indicates that circa 254 limited companies were registered of which 218 have complete files. With only a couple of exceptions, all companies on the list are Chinese businesses, both managed and owned by Chinese. As a consequence of a fire that destroyed the British records, the Japanese re-registration constitutes the only surviving firm level data for the Hong Kong economy before the 1950's, Chung Wai Kung, "The Organisation of Chinese Businesses in Hong Kong During 1940s", presented at The Rise of Business Corporations in China from Ming to Present at the Centre of Asian Studies, The University of Hong Kong, 12-13 July 1996.

18 By March 1995 there were 636,312 businesses registered under the Registration of Businesses Ordinance and in excess of 470,000 registered companies.

19 The Hong Kong Companies Ordinance was until recently based on the UK Companies Act 1929. In 1984 it underwent substantial updating which has continued on an almost annual basis since. Similarly the Hong Kong Securities Ordinance bears a remarkable resemblance to the New South Wales Securities Industry Act 1975.

20 As at 31 December 1995 there were 6322 public companies on the register of companies in Hong Kong. Of these, 5655 were companies limited by guarantee: Company Registry Statistics 1995.

21 See Rules Governing the Listing of Securities on the Stock Exchange of Hong Kong Ltd, r 8.08 and 8.09 .

22 As at 31 December 1995 there were 465,561 private companies on the register: Company Registry Statistics 1995.

23 E L G Tyler, "Some Comments on Recent Hong Kong Incorporation Figures" HKICSA (1996) Company Secretary, Forthcoming.

24 By the end of 1995 of the 544 listed companies, 203 were registered in Hong Kong, 263 in Bermuda and 51 in the Cayman Islands.

25 S G Redding, supra n 11 at 3. 
26 This is not to say that the "contract" the most common form of business institution was unknown in China, quite the contrary for the common use of contracts, in land transfer and partnership agreements suggests that contracts were widely used, D Faure, "Capitalism and the History of Chinese Business", presented at The Rise of Business Corporations in China From Ming to Present, Centre of Asian Studies, The University of Hong Kong, 12-13 July 1996.27 S G Redding, supra n 11 at 136-7, 213-7; S L Wong, supra n 12.

28 D Faure, "The Lineage as Business Company: Patronage Versus Law in the Development of Chinese Business". Paper presented at the Second Conference on Modern Chinese Economic History, The Institute of Economics, Academic Sinica, Taipei, Taiwan, 5-7 January 1989, pp 347-76.

29 The role of Asian religion representing core societal values played a central role in economic development. For Weber the "tension" between religious ideals and practical reality was important. Its capacity to explain why some cultures strive to change the world and others (those without the tension) see the world as unchangeable. For Weber Protestantism particularly was all about change and control, whereas Confucianism was all about the preservation of the status quo: M Weber, The Religion of China, 1951, pp 237, 241, 277. See generally R N Bellah, Religion and Progress in Modern Asia, 1965, p 145, Redding, supra, n 11 at $139-41$.

30 Yinwenzi: Yinxun; of n 36 infra.

31 For a positive view and examples of the influence of Confucianism, expressed in the form of clan or tongxiang relationships, on economic developments in Japan and the "Four Little Dragons", see Du Xuncheng Zhong Guo Chuan Tong Lun Li Yu Jin Dai Zi Ben Zhu Yi (Traditional Chinese Ethics and Recent Capitalism) Shanghai: Shanghai She Hui Ke Xue Yuen Press, 1993 56-61; for an illustration of the tongxiang phenomenon in the traditional Chinese commercial community, ibid 133-43. Contrast Redding supra n 11 at 111.

32 On the ground that if two persons have the same surname, they may be descendants of the same ancestor.

33 For a consideration of this phenomenon in the context of the enforcement of foreign arbitral awards in China see KY Wong and D Roebuck, "The Influence of Traditional Morality on the Enforcement of Foreign Arbitral Awards in China", (1995) 5 AJCL 342.

34 W K Gabrenyu, Jr and K K Hwang "Chinese Social Interaction: Harmony and Hierarchy on the Good Earth" in The Handbook of Chinese Psychology, M H Bond, OUP, Hong Kong 1996 at 319.35 G Hamilton, "Patriarchy, Patrimonialism and Filial Piety: A Comparison of China and Western Europe", (1990) 41 British Journal of Sociology 77.

36 Fei Xiatung, Xiangtu Zhongguo (Rural China), Hong Kong, Joint Publishing Co 1986 chs 4 and 5.37 Hamilton, supra n 35 at 99.

38 Gabrenya and Hwang, supra, n 34, P B Smith and Z M Wang, "Chinese Leadership and Organisation Structures" in The Handbook of Chinese Psychology ed M H Bond, OUP, Hong Kong 1996 at 322-37; cf CAG Jones, "Capitalism, Globalisation and Rule of Law: An Alternative Trajectory of Legal Change in China", (1994) Social Legal Studies 195; A Smart, "Gifts, Bribes and Guanxi: a Reconsideration of Bourdieu's Social Capital" (1993) 8 Cultural Anthropology 388; R Tomasic, "Company Law and the Limits of the Rule of Law in China" (1995) 4 AJCL 470; Redding, supra n 11, ch 5.

39 J Child, Management in China During the Age of Reform, Cambridge University Press, 1994, at 145 .

40 For several anecdotal examples see N D Kristoff and S Wudunn, China Wakes, Nicholas Brealey Publishing, London, 1994, in particular the cases of Tang Rimei and Boss Wong at pp 27-30; Wang Chaoru and Grandma Zhang at 94-103; Wang Zhiqiang and fake medicine at $188-91$; the case of the recycled hypodermic needles at 356-8 and for an overseas chinese entrepreneur allegedly using political contacts to circumvent the law see A L Neuman,"Who Loves Lucio" Asia Inc Vol 5 No 8 August 1996 at 21-6; of A H Yee, A People Misruled: The Chinese Stepping Stone Syndrome 2nd ed, Heinemann Asia, Singapore, 1992, at 160-1; T W Lo, Corruption and Politics in Hong Kong and China, Open University Press, Buckingham 1993; R P L Lee (ed), Corruption and its Control in Hong Kong, Chinese University Press, Hong Kong, 1981.

41 R I Tricker, "Corporate Governance: A Ripple on the Cultural Reflection" in Capitalism in Contrasting Cultures, eds S R Clegg and S G Redding, Walter de Gruyter, 1990. 
42 Redding, supra $\mathrm{n} 11$ at 141 . As to problem of translation, see D Roebuck and K K Sin, "The Ego and I and Ngo: Theoretical Problems in the Translation of the Common Law into Chinese" in Hong Kong, China and 1997: Essays in Legal Theory, ed R Wacks, Hong Kong University Press 1993; cf, J T Wu and I M Liu "Chinese Lexical Access"; H C Chen, "Chinese Reading and Comprehension: A Cognitive Psychology Perspective", C K Leong and S Hsiu "Cross Linguistic Constraints on Chinese Students Learning English" in The Handbook of Chinese Psychology, ed M H Bond, OUP, Hong Kong 1996.

43 Discussion with former SFC officials and members of the HK Company Law Reform Committee.

44 Victor Li (son of Li Ka Shing) quoted in D Gutslein, The New Landlords: Asian Investment in Canadian Real Estate, Press Parcepic, Vancouver, 1990.

45 Redding, supra n 11 at 195.

46 S L Wong, "The Chinese Family Firm: A Model" (1985) 36 The British Journal of Sociology 58 at 64.

47 J P Scott, "Corporate Control and Corporate Rule: Britain in an International Perspective" (1990) 41 British Journal of Sociology 351 at 371.

48 For a discussion of this adaptation in a historical context see E L G Tyler, "Does the Complexity of Companies Legislation Impede Entrepreneurship? The Hong Kong Experience" delivered at the Conference on Market Forces and the Law, Beijing University 21-2 October 1994.

49 Redding, supra $\mathrm{n} 11$ at 155 . It has been argued that authority relations identified by the terms patriarchy, patrimonialism, and filial piety represent very different complexes of action in Imperial China and Western Europe, G Hamilton, "Patriarchy, Patrimonialism, and Filial Piety: A Comparison of China and Western Europe" (1990) 41 British Journal of Sociology 77. 50 Redding, supra $\mathrm{n} 11$ at 158, 159. Exceptional examples include Mr Li Ka Shing, Sir Y K Pao, Mr Fung King Hey, Mr Liem Sioe Liong. See generally Redding, supra n 11 at 165, 207-12. See also Child, supra $\mathrm{n} 39$ at chs 5, 8. It may be noted that Li Ka Shing's delegation of management responsibilities may be out of necessity. Amongst the largest Chinese family owned or controlled enterprises in Hong Kong both listed and unlisted his holdings are amongst the small minority in which the founder has so few blood relatives in control. He has no brother and no sister in Hong Kong. His sons are young for a man of his age although both of them are in the family business. In the years of business expansion Lee simply had to delegate. There are numerous examples of family managed second and third generation companies: eg the Garden Co Ltd (known as the baker to Hong Kong) is run now by three sons and two daughters of the founder; the Lui Chong Hing Bank is now run by the Lui Brothers, sons of the founder. Lee Kam Kee Ltd, the oyster sauce company, Wing On Co Ltd, the merchandiser, are run by the sons and grandsons of their founders. The Bank of East Asia and the Wing Lung Bank are still run by the sons and daughters of the founding families. Cf the study of the Sincere Co Ltd in P Lawton, "Expanding Shareholder Control in Hong Kong" in Legal Developments in China: Market Economy and the Law, ed G G Wang and Z Y Wei, Sweet and Maxwell, Hong Kong 1996, at 88-9. For a changing perspective see "Like Father, Unlike Son", World Executive Digest August 1996, 26.

51 Cf supra n 13.

52 Redding, supra n 11 at 178.

53 Cf L Sunyadinata, "Chinese Economic Elites in Indonesia: A Preliminary Study" in Changing Identities of the Southeast Asian Chinese since World War II, ed J Cushman and G W Wang, HKU Press (1988); J Cushman, "The Khaw Group: Chinese Business in Early Twentieth Century Penang", (1986) 17 Journal of Southeast Asia Studies 58-79.

54 Redding, supra n 11 at 214.

55 See generally ibid, ch 9 "Sources of efficiency and failure".

56 Ibid at $219-20$.

57 In other South East Asian countries there are examples of successful conglomerates see for example Y Sato "The Salim Group in Indonesia: The Development and Behaviour of the Largest Conglomerate in Southeast Asia" (1993) 31 The Developing Economies 408-41; and for a successful conglomerate along the lines described by Redding see I Numazaki, "The Tainanbary: The Rise and Growth of a Banana-Bunch-Shaped Business Group in Taiwan" (1993) 31 The Developing Economies 485-509, and for the Chinese family business in Thailand 
see A Suehiro, "Family Business Reassessed: Corporate Structure and Late Starting Industrialisation in Thailand", (1993) 31 The Developing Economies 378-407.

58 Douglas Clague was also responsible for building the first cross harbour tunnel in $\mathrm{HK}$, cf D Wilson, Hong KongUnwin Hyman London, 1990 at 186.

59 See Generally Sources in $\mathrm{n} 13$ supra.

60 See Faure, supra, n 26; R A Brown, "Chinese banking Networks in SE Asia"; presented at The Rise of Business Corporations in China From Ming to Present, Centre of Asian Studies, The University of Hong Kong 12-13 July 1996.

61 Wilson, supra n 58 at 164 and see generally ch 17.

62 Faure, supra n 26 at 22 . The only competition in later periods, for example the late nineteenth and early twentieth century was from Western capital, but even here the institution of the compradore assisted in funnelling Western capital into Chinese"mixed" banking cartels; Brown, supra n 60; cf P T Lee, "Business Networks and Patterns of Cantonese Compradors and Merchants in Nineteenth Century Hong Kong (1995) Journal of the Hong Kong Branch of the Royal Asiatic Society 1.

63 Redding, supra n 11 at 212.

64 Ibid at 213 and 219.

65 Child supra n 39, ch 11.

66 Contrast the development of the British Brewing Industry where after incorporation in the later 1890 s and early 1900 s, many brewing companies operated much as they had done before, ie as Family businesses, but many made the transition from a family based to a more professional top management in the period 1914-55. The introduction of trained brewers, company secretaries, lawyers and later, accountants, to brewing boards gave companies more of the skills necessary to the effective supervision of a modern business enterprise. This helped with problems of succession. T R Gourvish and R G Wilson, The British Brewing Industry 18301980, CUP, Cambridge, 1994, at 389 et seq.

67 In one Securities and Futures Commission investingation into the affairs of a Hong Kong listed company it was discovered that the head of the company often made a decision which would then be communicated, inter alia, by telephone message to board members as a de facto decision of the board. Interview with former SFC official.

68 According to one recent report into the role of the company secretary in Hong Kong up to $67 \%$ of listed companies delegate shareholder registration and relations to outside firms, Tricker et al, The Company Secretary in Hong Kong's Listed Companies, HKICSA, 1995 at 6-9. 69 Cf paper by John Brewer FCIS, Chief Executive HKICSA, "The Legal Liabilities of the Company Secretary" at the Asian Law Journals Conference on Company Secretaries Legal Liabilities, 28 October 1994 Century Hotel Hong Kong. Cf "Share transfers to names of nominees" South China Morning Post (SCMP) 18 April 1996.

70 P Lawton, "Corporate Governance and Informal Decision Making: The Theoretical and Practical Limits of Hong Kong's Legal Regime", (1995) 1 Corporate Governance Quarterly (Issue 1) 17-24; (Issue 2) 29-41.

71 Interview with management consultant.

72 S Hill, "The Social Organisation of Boards of Directors", (1995) 46 British Journal of Sociology 245 at 253.

73 Note the differences between British and German managers in this respect. The latter have a relatively low power distance score like the British but a high uncertainty avoidance score, cf G Hofstede, Culture and Organisations: Software of the Mind, McGraw Hill (Europe), 1991 at 109-17. Their differences in attitudes to and use of meetings are markedly different as are their attitude to the tolerance for ambiguity and use of humour to ease relationships and conflict and note the marked British practice of injecting humour into most mundane requests to cancel any hint of authoritarianism; R Stewart, J L Barsoux et al, Managing in Britain and Germany, St Martins Press, New York, 1994, at 97-8 and 168-71.

74 I Björkman, "The Board of Directors in Sino-Western Joint Ventures", (1995) 3 Corporate Governance 156 at 164 .

75 S Stewart, "China's Managers", (1992) 34 The International Executive 165 at 176.76 Ibid 
at 178.

77 Child, supra n 39 at 152-3.

78 Ibid, at 153.

79 Ibid, at 39.

80 Charkham, supra n 4 at 264, Hill, supra n 72.

81 Ibid at 267.

82 Ibid at 268.

83 P Lawton, "Directors' Remuneration, Benefits and Extractions, an Analysis of their Uses, Abuses and Controls in the Corporate Government Context of Hong Kong" (1995) 4 AJCL 430, at 452-5.

$84 \mathrm{~J}$ Scott, "Theoretical Framework and Research Design" in Networks of Corporate Power, eds F N Stokman, R Zeigler and J Scott, Polity Press, Cambridge, 1985.

85 Scott, supra n 84 at 13.

86 Speech given at HKICSA Conference "Advice to Directors and the Board - the Critical Issues" 3 December 1994.

87 G Wong, "The Changing Patterns of Interlocking Directorates in Hong Kong - The Effects of the Rise of Chinese Big Business in the Period 1976-1986", paper presented at the conference The Last Half Century of the Chinese Overseas (1945-1994): Comparative Perspectives, University of Hong Kong, 19-21 December 1994 at 9-10.

88 Redding, supra n 11 at 218-19.

89 S Fluendy, "Call for Action on Directors", South China Morning Post (SCMP) 18 October 1994.

90 Bell v Lever Bros Ltd [1932] AC 161, HL at 194; Harkness v Commonwealth Bank of Australia Ltd (1993) 32 NSWLR 543.

91 House of Commons, First Report from the Committee of Public Accounts Session 1985-6, "Role and Responsibilities of Nominee Directors", vii.

92 Hilmer Committee, Strictly Boardroom at 33.

93 Ibid ch 3.

94 See Noel Fung, "Shareholders Vote Family Out of Group" South China Morning Post 29 September 1995. Excessive remuneration and large unsecured loans to associated companies were some of the causes of the split in the family. This is a modern Hong Kong example of Cohen's description of the processes by which a joint family's sense of harmony (du wo) is sabotaged from within: "it seems clear that a deliberate effort to force partition is involved when a family's sharing practices are increasingly compromised by the refusal of some individuals to contribute their labour and time or by the outright embezzlement of family funds", M L Cohen, House United, House Divided: The Chinese Family in Taiwan, Columbia University Press, New York, 1976 at 204.

95 Cf Redding, supra n 11 at 133.

96 Cf D Devoes, "A Major Business Asset", Asia Inc (1994) Vol 3 No 9 at 33-9.

97 Cf T Dobson, "Equity Joint Ventures' in Trade and Investment Law in Hong Kong, eds P Smart and A Halkyard Butterworth Asia 1993.

98 Child, supra n 39 at 241.

99 J L Schaan, "How to Control a Joint Venture even as a Minority Partner", (1988) 14 Journal of General Management 4 at 4-5.

100 Child, supra n 39 at 243.

101 Bjorkman, supra n 74. See also P B Smith and Z M Wang, "Chinese Leadership and 
Organisational Structures" in The handbook of Chinese Psychology ed M H Bond, OUP, Hong Kong, 1996.

102 Child, surpa, n 39, at 261, 267 and 269.

103 Ibid, at 269 and 271.

104 Ibid, at 270 and 275.

105 Ibid, at 273.

106 Ibid, at 280 .

107 Ibid, at 277.

108 See eg R I Westwood (ed) Organisational Behaviour: Southeast Asian Perspectives, Longman Far East (1992). The cultural bias is very difficult for Anglo-American researchers, and those influenced by them, to avoid, given that nearly all of their constructs and theories for understanding and categorising management emanate from the highly individualistic AngloAmerican countries, Stewart et al, supra, n 73 at 197.

109 G Hofstede, Cultures and Organisations: Software of the Mind, McGraw Hill (Europe), 1991.

110 F Trompenaars, Riding the Waves of Culture, Nicholas Brealey Publishing, London, 1993.

111 For an explanation of this concept see Hofstede, supra n 109 at 24-28. For a comparison with Trompenaars see Smith and Wang, supra n 101 at 324-7.112 Yee, supra n 40 at 162-3.

113 M Baisot and X G Liang, "The Nature of Managerial Work in the Chinese Enterprise Reforms: A Study of Six Directors", (1992) 13 Organisation Studies 161-84, cf Smith and Wang, supra $\mathrm{n} 101$ at 327.114 Smith and Wang, supra $\mathrm{n} 101$ at 331 , see also J F Yates and J W Lee, "Chinese Decision Making" in The Handbook of Chinese Psychology, ed M H Bond, OUP, Hong Kong. 1996.

115 Gabrenya and Hwang, supra n 34 at 314-6, 319.

116 Yates and Lee, supra n 114 at 344-7.

117 For an explanation of this concept see Hofstede, supra n 109 , ch 5 . For a consideration of this issue see Smith and Wang supra n 101 at 325.

118 The original score for Taiwan is 69, Hong Kong 29 and Singapore 8, Hofstede supra n 109 at 113. The table on p 324 for Hofstede's scores of Smith and Wang supra, n 101 appears to be inaccurate and does not correspond with the text on $p 325$. For insight into the philosophical ambiguity of the Chinese mind see RE Allison, "An Overview of The Chinese Mind" in Understanding the Chinese Mind: The Philosophical Rootsed R E Allison, OUP, Hong Kong 1989.

119 For the ludditism of Chinese craftsmen and guilds in the nineteenth century, see D J MacGowan, "Chinese Guilds or Chambers of Commerce and Trade Unions", (1886) 21 Journal of the North China Branch of the Royal Asiatic Society 8, discussed in Kristoff and Wudunn, supra n 40 at 321. See also P T Ho, "Economic and Institutional Factors in the Decline of the Chinese Empire" in The Economic Decline of Empires ed Cippola, Meuthen, 1980; J Y Lin, "The Needham Puzzle: Why the Industrial Revolution Did not Originate in China" (1995) Journal of Economic Development and Cultural Changes 264.

120 Faure, supra n 26 at 13.

121 J Wang, "Chijiu shiji waiguo qinhau qiye zhong de naushang fugu huodong" (1965), Lishi Yanjiu, 4, discussed in Faure supra n 26 at 21.

122 For a consideration of the increased use of registered companies by Hong Kong Chinese Businessmen Post 1948 see EL G Tyler, "Does the complexity of Companies Legislation Impede Entrepreneurship? The Hong Kong Experience" paper delivered at the Conference on Market Forces and the Law, Beijing University 21-2 October 1994.

123 S L Wong, "The Chinese Family: Firm a Model", (1985) 36 The British Journal of Sociology 58.

124 Ibid, at 62. 
125 Suehiro, supra n 57 at 380.

126 T Hattori, "Ownership and Management of Contemporary Korean Enterprises" (1984) 25 Ajia Keizai Nos 5-6, May-June.

127 Wong, supra, n 123, at 64 .

128 Ibid, at 65.

129 Ibid, at 66-7.

130 Ibid, at 67-8.

131 Redding, supra $\mathrm{n} 11$ at 158 and 178.

$132[1973]$ AC 360.

133 [1980] BCLC 430.

134 [1959] 1 WLR 62.

135 [1937] Ch 392.

136 [1976] 2 All ER 268.

137 Suehiro, supra $n$ 57, has emphasised the success of extended polygamous family businesses giving each other mutual support, in a pro industrial context, observing a "clear intent on the part of family business to maintain intact and even expand the family's enterprises and assets over a number of generations" at 403 in contrast to the anti-industrial pro gentrification thesis of Useem in relation to Britain and the USA, of M Useem, The Inner Circle, OUP, New York, Oxford 1984.

138 Chinese Marriages Ordinance 1971.

139 Cf L F So, "Plea on Concubines" SCMP 30 January 1995 and E Ng and I Cheung, "Concubine Negates Registry Marriage", SCMP 31 December 1994.

140 See generally A P Wolf and C S Huang, Marriage and Adoption in China, 1845-1945, Stanford University Press, California 1980; M Jaschok, Concubines and Bondservants: The Social History of a Chinese Custom, OUP, Hong Kong, 1988.

141 S A Queen, R W Habenstein and J S Quadagno, The Family in Various Cultures at p 82; S C Lee, "China's Traditional Family, Its Characteristics and Disintegration" (1953) 18 American Sociological Review 272.

142 P B Ebrey, "Family Instructions" in The Chinese Adapting the Past, Building the Future, eds R F Dernberger, $\mathrm{K} J$ DeWoskin et al, The University of Michigan Center for Chinese Studies (1986).

143 Cf Re Estate of Kwan Kai Ming, deceased, 30 December 1994, HK MD No 2996 of 1990, unreported; Tsao Chin Lan v Tin Ka Kung 20 December 1994, HK Action No A7605 of 1991, unreported.

144 These include Re Taiwa Land Investment Co Ltd [1981] HKLR 297; Re Lai Kan Co Ltd and Re Safe Steel Furniture Factory Ltd [1988] HKLR 257; Re Bondwood Development [1990] 1 HKLR 200; Yuen San Fai v Yun Jip Auto Services Ltd (1992) 1 HKC 234; Lou Thiam Siong v Hwa Own Co (Hong Kong) Ltd (1988) CWU No 170 of 1988; Deacon Te Ken Chiu v Ronald Li Kai Chu [1991] 1 HKLR; Re Medavision Ltd (1993) 2 HKC 629; Prime Aim International Ltd v Cosmos Pavis International Ltd (1994) 2 HKC 545.

145 Between 1980 and 1995 there were circa 270 petitions issued in the High Court on the basis of just and equitable winding up, the majority of which made alternative claims on the basis of unfairly prejudicial conduct.

146 HK 1988 No CWN 185, unreported.

147 S L Wong, "The Chinese Family Firm Revisited: Hidden Dimensions" presented at conference entitled The Rise of Business Corporations in China from Ming to Present, Centre of Asian Studies, The University of Hong Kong 12-13 July 1996.

148 Suehiro, supra n 57. 
149 [1947] AC 22.

150 Cf P Leach, The Family Business (1995) Director Publications, (Stoy Centre for Family Business), London, 1995. The Stoy figures show that while $75 \%$ of UK companies are family run, only $30 \%$ of UK family business make it to the second generation and just $14 \%$ to the third, P Beresford, "The Independent Ones" (1995) Director (November issue) 109-15 at 113. For problems of succession in UK family companies see J Oliver, "Who's Next?" (1996) Management Today July, 56-8.

151 Charkham, supra, n 4 at 260-1. For a study of this double ancestry in the Australian context, see P Redmond, Companies and Securities Law: Commentary and Materials (2nd ed, 1992), LBC, Sydney.

152 K K Hwang, "Modernisation of the Chinese Family Business" (1990) 25 International Journal of Psychology 593-618 discussed in Smith and Wang supra, n 101.

153 T P Wang, The Origins of Chinese Kongsi, Pelanduk Publications, Malaysia, 1994.

154 There were 16 privatisations of public companies in 1991-2; 24 in 1992-3 and almost 30 in 1993-4. As a result, the SFC has altered the share buyback code to protect the bargaining position of the minority.

155 A Ngai, "Open Door Looms for Boardroom Brawls", Sunday Morning Post 12 February 1995.

156 See eg, the recent adventures of Mr Arthur Lai in Chingtung Futures Ltd v Arthur Lai, [1994] 1 HKLR 95 and R Gluckman, "MKI How an Investor's Sweet Dream became a Nightmare", (1995) Vol 4 No 3 Asia Inc at 26.

157 See P Lawton, "Director's Remuneration, Benefits and Extractions, an Analysis of their Uses Abuses and Controls in the Corporate Governance Context of Hong Kong" (1995) 4 AJCL 430.

158 In the last two years there have been two spectacular instances of "corporate raiders" purchasing a sufficiently large shareholding in listed companies to gain de facto control without triggering a TOB. The raiders have then proceeded to milk the companies by transferring assets to them at high overvalues. The victims tended to be well established, cash rich and with an untypically wide spread of shareholdings for Hong Kong. Cf Reports by Inspectors of Investigations under s 143(1)(C) of the Companies Ordinance by Mr Nicholas Allen into the affairs of the Allied Group Ltd and by John Robert Lees into the affairs of Tomson Pacific Ltd and World Trade Centre Group Ltd. For an example in the context of a private company see Mun Won Co Ltd and The Singapore-Johore Express (PTE) Ltd v Tay Vi Bing (1989) HK No A2553, unreported.

159 Faure supra n 26 at $26-7$.

160 Gower's Principles of Modern Company Law, 5th ed (1992), at p 70.

161 New Zealand Law Commission, Company Law Reform and Restatement, Report No 9, at p 11.

162 Ermano Pascutto, Hong Kong Companies Ordinance Inception Report: An Ordinance for the 21st Century at para 2.1.1.2. 